\title{
DVR Based Compensation of Voltage Sag due to Variations of Load: A Study on Analysis of Active Power
}

\author{
Anita Pakharia ${ }^{1}$, Manoj Gupta ${ }^{2}$ \\ Department of Electrical Engineering \\ ${ }^{1}$ Assistant Professor, Global College of Technology, Jaipur, Rajasthan, India \\ ${ }^{2}$ Professor, Poornima College of Engineering, Jaipur, Rajasthan, India
}

\begin{abstract}
Dynamic Voltage Restorer (DVR) has become very popular in recent years for compensation of voltage sag and swell. The voltage sag and swell is very severe problem of power quality for an industrial customer which needs urgent attention for its compensation. There are various methods for the compensation of voltage sag and swell. One of the most popular methods of sag and swell compensation is Dynamic Voltage Restorer (DVR), which is used in both low voltage and medium voltage applications. In this work, our main focus is on DVR. DVR compensate the voltage sag by injecting voltage as well as power into the system. The compensation capability of this is mainly influenced by the various load conditions and voltage dip to be compensated. In this work the Dynamic Voltage Restorer is designed and simulated with the help of Matlab Simulink for sag compensation. Efficient control technique (Park's Transformations) is used for mitigation of voltage sag through which optimized performance of DVR is obtained. The performance of DVR is analyzed on various conditions of active and reactive power of load at a particular level of dc energy storage. Parameters of load are varied and the results are analyzed on the basis of output voltages.
\end{abstract}

Keywords — Structure and control technique for dvr, dvr test system, power quality.

\section{INTRODUCTION}

Power quality $(\mathrm{PQ})$ issue has attained considerable attention in the last decade due to large penetration of power electronics based loads and microprocessor based controlled loads. On one hand these devices introduce power quality problem and on other hand these mal-operate due to the induced power quality problems. PQ disturbances cover a broad frequency range with significantly different magnitude variations and can be non-stationary, thus, appropriate techniques are required to compensate these events/disturbances [1].

The growing concern for power quality has led to development for variety of devices designed for mitigating power disturbances, primarily voltage sag and swell. Voltage sag and swell are most wide spread power quality issue affecting distribution systems, especially industries, where involved losses can reach very high values. Short and shallow voltage sag can produce dropout of a whole industry [2]. In general, it is possible to consider voltage sag and swell as the origin of 10 to $90 \%$ power quality problems. The main causes of voltage sag are faults and short circuits, lightning strokes, and inrush currents and swell can occur due to a single line-to ground fault on the system and also be generated by sudden load decreases, which can result in a temporary voltage rise on the unfaulted phases [1] [2].

The voltage sag and swell is very severe problem for an industrial customer which needs urgent attention for its compensation. Among several devices, a Dynamic Voltage Restorer (DVR) is a novel custom power device proposed to compensate for voltage disturbances in a distribution system. The dynamic voltage restorer is the most efficient and effective power device used in power distribution networks. Its appeal includes lower cost, smaller size, and its fast dynamic response to the disturbance. Our main focus in this thesis is on the Dynamic Voltage Restorer (DVR) [3]. This device using series-connected VSC is used to inject controlled voltage (controlled amplitude and phase angle) between the Point of Common Coupling (PCC) and the load [3] [4].

For proper voltage sag and swell compensation, it is necessary to derive suitable and fast control scheme for inverter switching. Here, we develop the simulation model using MATLAB SIMULINK and also discusses simulation results with different load conditions.

\section{STRUCTURE AND CONTROL TECHNIQUE FOR DVR}

DVR is connected in the utility primary distribution feeder. This location of DVR mitigates the certain group of customer by faults on the adjacent feeder as shown in fig. 1. The point of common coupling (PCC) feds 
the load and the fault. The voltage sag in the system is calculated by using voltage divider rule [5]. The general configuration of the DVR consists of:

(a) Series injection transformer (b) Energy storage unit

$\begin{array}{lll}\text { (c) Inverter circuit } & \text { (d) Filter unit }\end{array}$

(e) DC charging circuit (f) A Control and Protection system

Energy storage device is the most expensive component of the DVR, therefore it is essential requirement to use such mitigation strategy at which DVR can operate with minimum energy storage requirement. Different voltage sag mitigation strategies including pre-sag, in-phase, and phase advance compensation have described in this thesis. Injection of active power by DVR is related to energy storage. DVR injecting large amount of active power requires bigger size of energy storage leading to more expensive scheme. Therefore, optimization of energy storage can be obtained by optimizing DVR active power injection. In case of zero active power injection by DVR, it injects reactive power only to compensate for voltage sag [6] [7].

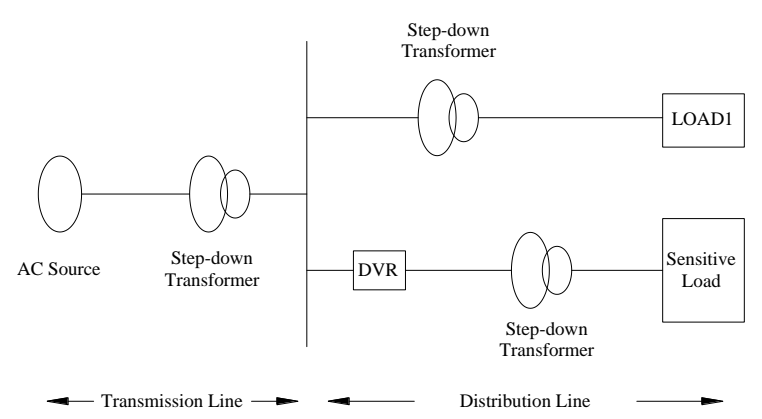

Fig. 1 Location of DVR

Control of DVR is performed by using d-q coordinate system. This transformation allows DC components, which is much simpler than $\mathrm{AC}$ components.

The dqo transformation or Park's transformation is used to control of DVR. The dqo method gives the sag depth and phase shift information with start and end times. The quantities are expressed as the instantaneous space vectors. Firstly convert the voltage from a-b-c reference frame to d-q-o reference [8].

$\left[\begin{array}{c}V_{d} \\ V_{\mathrm{q}} \\ V_{\mathrm{o}}\end{array}\right]=\left[\begin{array}{ccc}\cos (\theta) & \cos \left(\theta-\frac{2 \pi}{3}\right) & 1 \\ -\sin (\theta) & -\sin \left(\theta-\frac{2 \pi}{3}\right) & 1 \\ \frac{1}{2} & \frac{1}{2} & \frac{1}{2}\end{array}\right]\left[\begin{array}{c}\mathrm{V}_{\mathrm{a}} \\ \mathrm{V}_{\mathrm{b}} \\ \mathrm{V}_{\mathrm{c}}\end{array}\right]$

Above equation 1 defines the transformation from three phase system a, b, c to dqo stationary frame. In this transformation, phase $\mathrm{A}$ is aligned to the $\mathrm{d}$ axis that is in quadrature with the q-axis [9]. The theta $(\theta)$ is defined by the angle between phases $\mathrm{A}$ to the d-axis. The error signal is used as a modulation signal that allows generating a commutation pattern for the power switches (IGBT's) constituting the voltage source converter. The commutation pattern is generated by means of the sinusoidal pulse width modulation (SPWM) technique, voltages are controlled through the modulation [8] [9].

\section{DVR TEST SYSTEM}

Electrical circuit model of DVR test system is shown in fig.2. System parameters are listed in table 1. Voltage sag is created at load terminals via a three-phase fault. Load voltage is sensed and passed through a sequence analyzer [10]. The magnitude is compared with reference voltage. MATLAB Simulation model of the DVR is shown in fig. 3 which is display at the end if this paper. Table 1 shows the values of system parameters. System comprises of $15 \mathrm{kV}, 50 \mathrm{~Hz}$ generator, feeding transmission lines through a 3-winding transformer connected in $\mathrm{Y} / \Delta / \Delta, 15 / 115 / 11[10][11]$. 


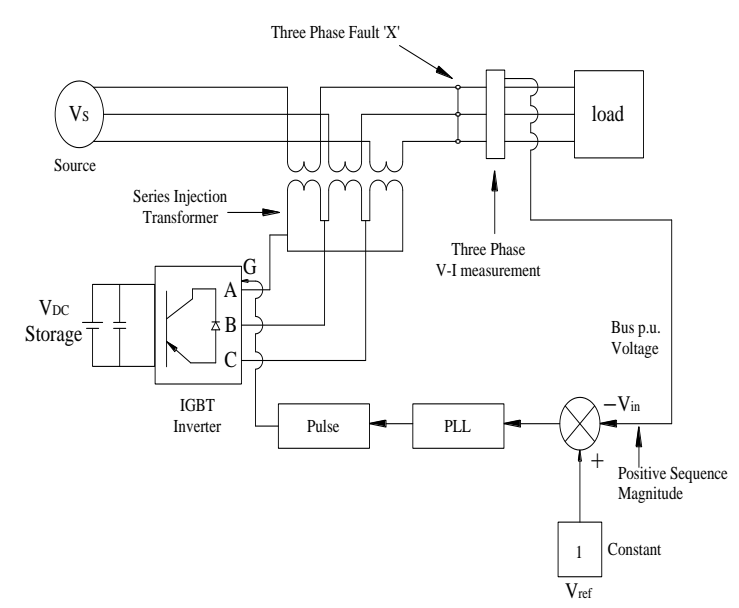

Fig. 2 Circuit Model of DVR Test System

TABLE 1 SYSTEM PARAMETERS

\begin{tabular}{|c|l|l|}
\hline S.No. & System Quantities & \multicolumn{1}{|c|}{ Ratings } \\
\hline 1. & $\begin{array}{l}\text { Main Supply } \\
\text { Voltage Per Phase }\end{array}$ & $15 \mathrm{KV}$ \\
\hline 2. & Line Impedance & $\mathrm{L}_{\mathrm{s}}=0.006 \mathrm{H}, \mathrm{R}_{\mathrm{s}}=0.002 \Omega$ \\
\hline 3. & $\begin{array}{l}\text { Series Transformer } \\
\text { Turns Ratio }\end{array}$ & $1: 1$ \\
\hline 4. & Filter Inductance & $1 \mathrm{mh}$ \\
\hline 5. & Filter Capacitance & $0.50 \mu \mathrm{F}$ \\
\hline 6. & Load Resistance & $40 \Omega$ \\
\hline 7. & Load Inductance & $0.05 \mathrm{H}$ \\
\hline 8. & Line Frequency & $50 \mathrm{HZ}$ \\
\hline 9. & $\begin{array}{l}\text { Inverter } \\
\text { Specifications }\end{array}$ & $\begin{array}{l}\text { IGBT Based, 3 Arms, } 12 \\
\text { Pulse, } \\
\text { Carrier Frequency }=1024 \mathrm{HZ} \\
\text { Sample Time= 0.5 sec. }\end{array}$ \\
\hline
\end{tabular}

Here, the outputs of a three-phase half-bridge inverter are connected to the utility supply series transformer. Once a voltage disturbance occurs, with the aid of dqo transformation based control scheme (Park's Transformation), the inverter output can be steered in phase with the incoming ac source while the load is maintained constant. As for the filtering scheme of the proposed method, output of inverter is installed with capacitors and inductors [11] [12].

\section{SimUlation ReSUlts}

Dynamic Voltage Restorer is simulated using MATLAB SIMULINK and the results are analyzed on the basis of output voltage. Various cases of different active power of load at different dc energy storage are 
considered to study the impact on sag waveform and compensated waveform as shown in fig. 4 to 15 . These various cases are listed in table 2 and discussed below.

Case I : A three-phase fault is created via a fault resistance of $0.55 \Omega$, load 1 is $5 \mathrm{KW}, 100 \mathrm{VAR}$ and load 2 is $10 \mathrm{KW}, 100 \mathrm{VAR}$ which results in a voltage sag of $10.07 \%$. Transition time for the fault is considered from 0.1 sec to $0.14 \mathrm{sec}$ as shown in fig.4. Fig.5 and 6 shows the voltage injected by the DVR and the corresponding load voltage. The simulation results and DVR performance in presence of dc energy storage reveals that $99.43 \%$ of sag is compensated and deviation of $0.57 \%$ is attained from three phase source voltage with $600 \mathrm{~V}$ of dc energy storage

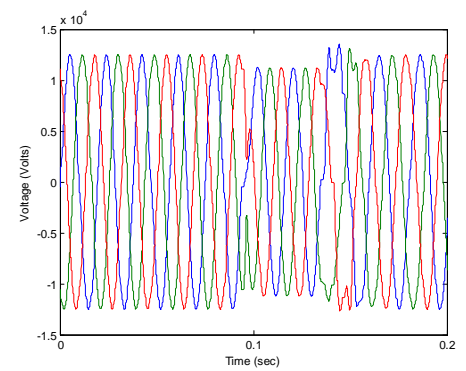

(a)

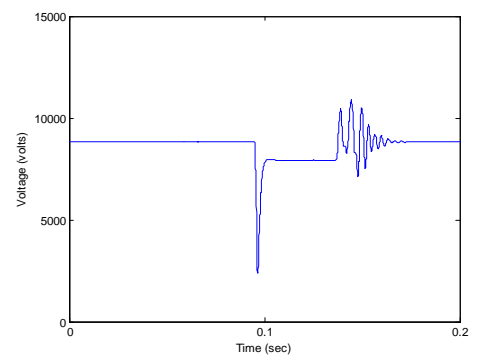

(b)

Fig. 4 Three phase voltage sag at load $5 \mathrm{KW}, 100 \mathrm{VAR}$ :

(a) Source voltage (b) RMS value of source voltage

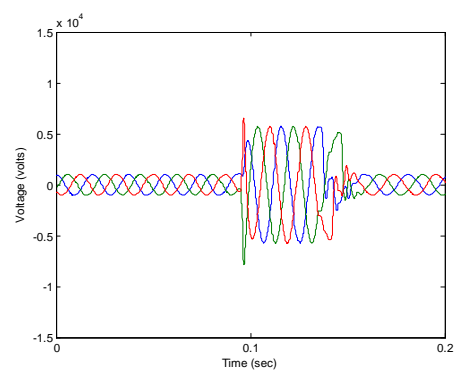

(a)

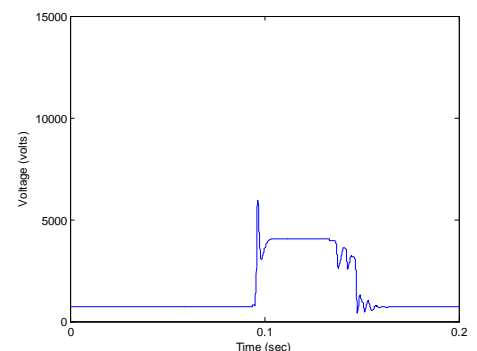

(b)

Fig. 5 Three phase injected voltage at load $5 \mathrm{KW}, 100$ VAR:

(a) Injected voltage (b) RMS value of injected voltage 


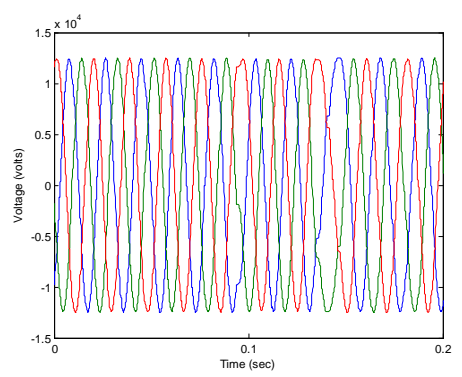

(a)

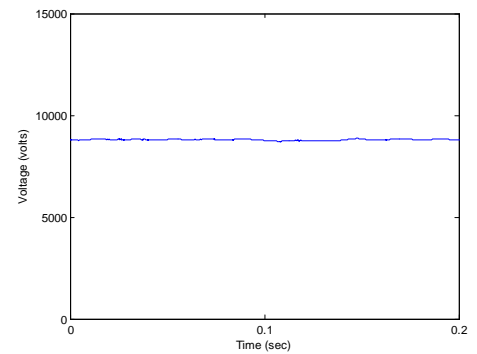

(b)

Fig. 6 Three Phase Compensated Voltage at load 5 KW, 100 VAR:

(a) Load (Improved) Voltage (b) RMS Value of Load (Improved) Voltage

Case II : A three-phase fault is created via a fault resistance of $0.55 \Omega$, load 1 is $10 \mathrm{KW}, 100 \mathrm{VAR}$ and load 2 is $10 \mathrm{KW}, 100 \mathrm{VAR}$ which results in a voltage sag of $28 \%$. Transition time for the fault is considered from $0.1 \mathrm{sec}$ to $0.14 \mathrm{sec}$ as shown in fig.7. Fig. 8 and 9 shows the voltage injected by the DVR and the corresponding load voltage. The simulation results and DVR performance in presence of dc energy storage reveals that $98.46 \%$ of sag is compensated and deviation of $1.54 \%$ is attained from three phase source voltage with $3.1 \mathrm{KV}$ of dc energy storage.

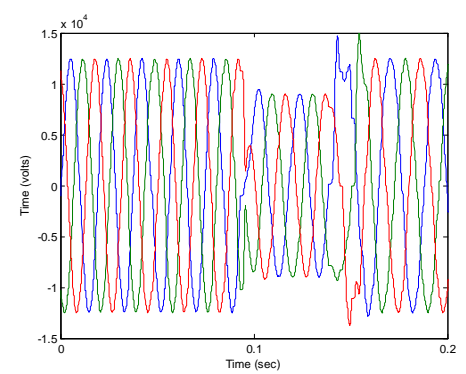

(a)

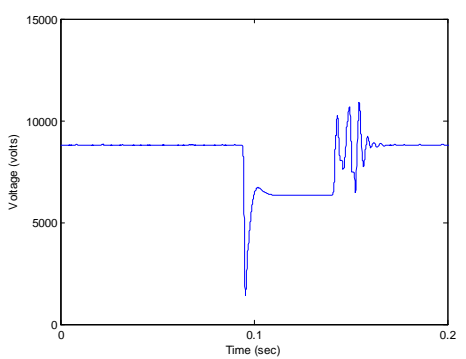

(b)

Fig. 7. Three phase voltage sag at load10 KW, $100 \mathrm{VAR}$

(a) Source voltage (b) RMS value of source voltage 


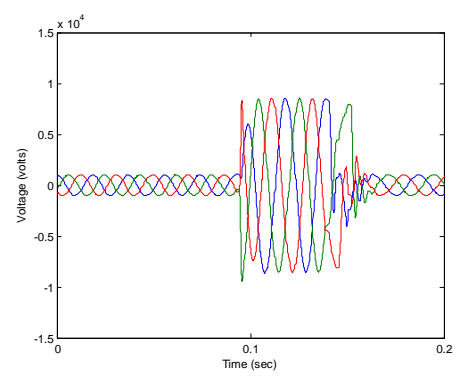

(a)

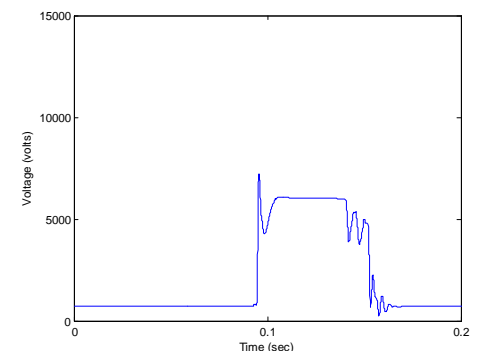

(b)

Fig. 8. Three phase injected voltage at load $10 \mathrm{KW}, 100 \mathrm{VAR}$ :

(a) Injected voltage (b) RMS value of injected voltage

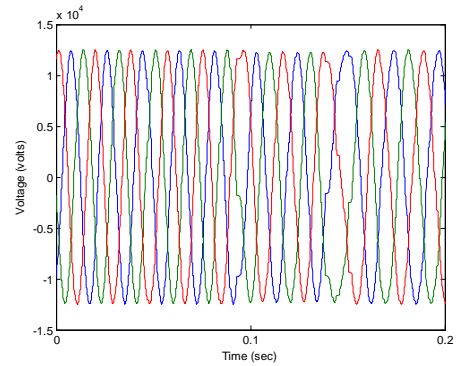

(a)

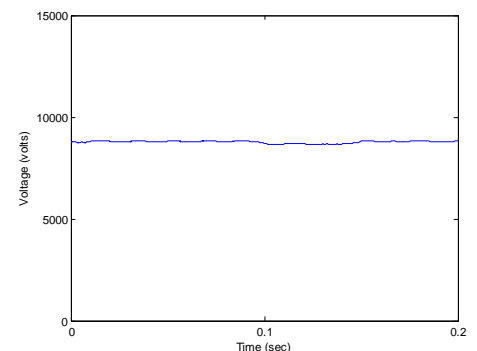

(b)

Fig. 9. Three phase compensated voltage at load $10 \mathrm{KW}, 100$ VAR:

(a) Load (improved) voltage (b) RMS value of load (improved) voltage

Case III : A three-phase fault is created via a fault resistance of $0.55 \Omega$, load 1 is $50 \mathrm{KW}, 100 \mathrm{VAR}$ and load 2 is $10 \mathrm{KW}, 100 \mathrm{VAR}$ which results in a voltage sag of $80 \%$. Transition time for the fault is considered from 0.1 sec to $0.14 \mathrm{sec}$ as shown in fig. 10. Fig.11 and 12 shows the voltage injected by the DVR and the corresponding load voltage. The simulation results and DVR performance in presence of dc energy storage reveals that 97.96 $\%$ of sag is compensated and deviation of $2.03 \%$ is attained from three phase source voltage with $8.5 \mathrm{KV}$ of dc energy storage. 


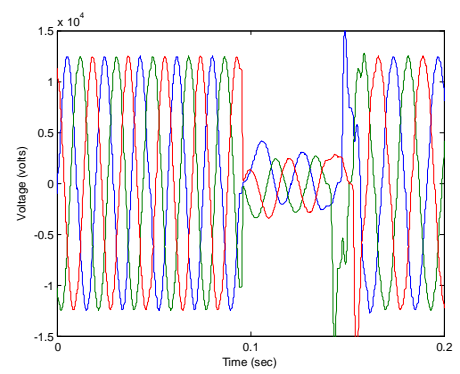

(a)

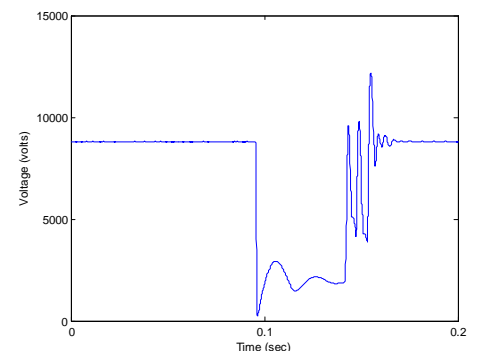

(b)

Fig. 10. Three phase voltage sag at load $50 \mathrm{KW}, 100 \mathrm{VAR}$ :

(a) Source voltage (b) RMS value of source voltage

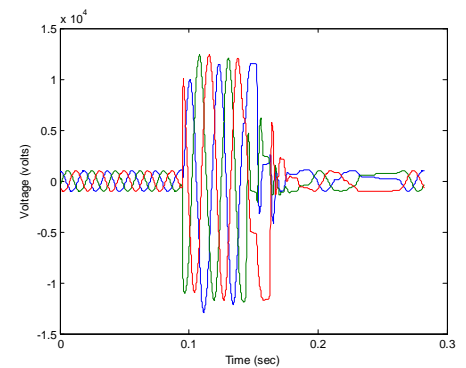

(a)

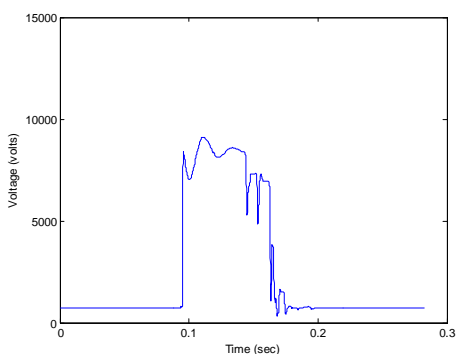

(b)

Fig. 11. Three phase injected voltage at load $50 \mathrm{KW}, 100 \mathrm{VAR}$ :

(a) Injected voltage (b) RMS value of injected voltage

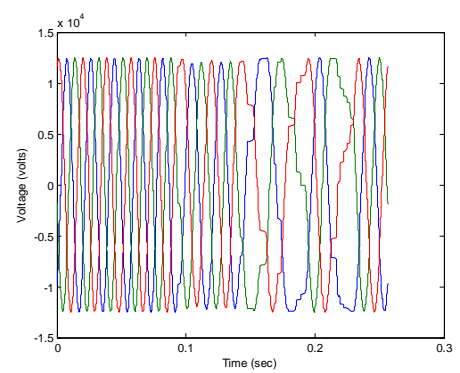

(a) 


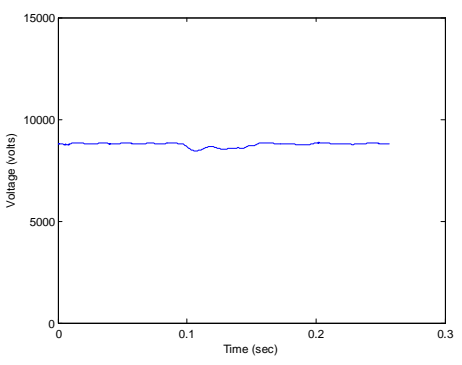

(b)

Fig. 5.12. Three phase compensated voltage at load $50 \mathrm{KW}, 100 \mathrm{VAR}$ :

(a) Load (improved) voltage (b) RMS value of load (improved) voltage

Case IV : A three-phase fault is created via a fault resistance of $0.55 \Omega$, load 1 is $1 \mathrm{MW}, 100 \mathrm{VAR}$ and load 2 is $10 \mathrm{KW}, 100 \mathrm{VAR}$ which results in a voltage sag of $97.12 \%$. Transition time for the fault is considered from 0.1 sec to $0.14 \mathrm{sec}$ as shown in fig.13. Fig. 14 and 15 shows the voltage injected by the DVR and the corresponding load voltage. The simulation results and DVR performance in presence of dc energy storage reveals that 99.39 $\%$ of sag is compensated and deviation of $0.61 \%$ is attained from three phase source voltage with $13 \mathrm{KV}$ of dc energy storage.

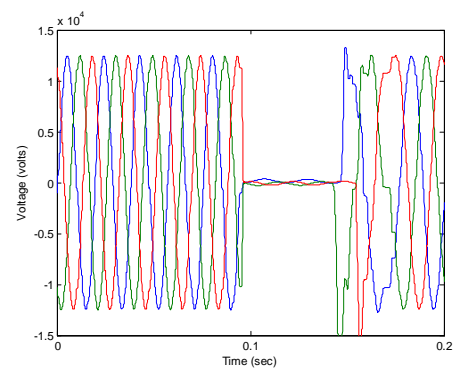

(a)

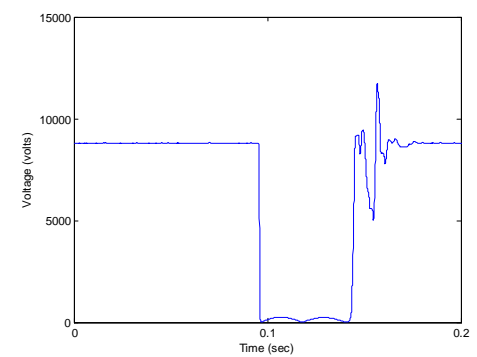

(b)

Fig. 5.13. Three phase voltage sag at load $1 \mathrm{MW}, 100 \mathrm{VAR}$ :

(a) Source voltage (b) RMS value of source voltage

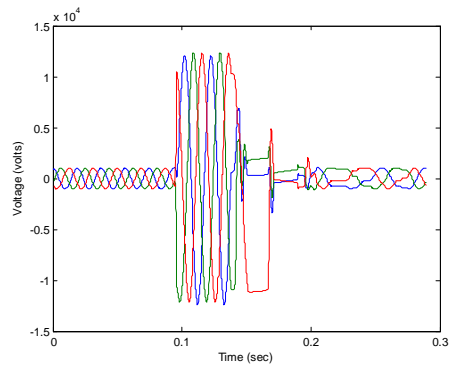

(a) 


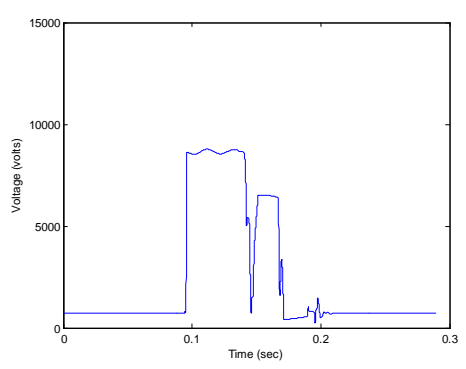

(b)

Fig. 5.14. Three phase injected voltage at load $1 \mathrm{MW}, 100 \mathrm{VAR}$ :

(a) Injected voltage (b) RMS value of injected voltage

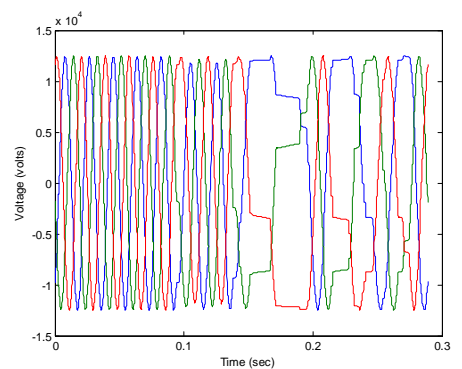

(a)

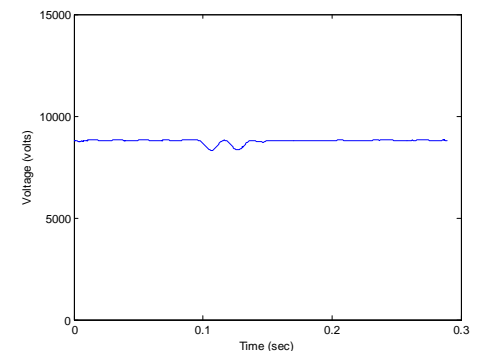

(b)

Fig. 5.15. Three phase compensated voltage at load $1 \mathrm{MW}, 100 \mathrm{VAR}$ :

(a) Load (improved) voltage (b) RMS value of load (improved) voltage

TABLE 2 VARIATIONS With PARAMETERS OF ACTIVE POWER OF LOAD

\begin{tabular}{|c|c|c|c|c|c|c|c|}
\hline Case & Load 1 & Load 2 & $\begin{array}{c}\text { Fault } \\
\text { Resistance }\end{array}$ & Sag & $\begin{array}{c}\text { DC Energy } \\
\text { Storage }\end{array}$ & $\begin{array}{c}\text { Compensated } \\
\text { Voltage }\end{array}$ & $\begin{array}{c}\text { Devi } \\
\text { ation }\end{array}$ \\
\hline I & $5 \mathrm{KW}, 100 \mathrm{VAR}$ & $10 \mathrm{KW}, 100 \mathrm{VAR}$ & $0.55 \Omega$ & $10.07 \%$ & $600 \mathrm{~V}$ & $99.43 \%$ & $\begin{array}{c}0.57 \\
\%\end{array}$ \\
\hline II & $\begin{array}{c}10 \mathrm{KW}, 100 \\
\mathrm{VAR}\end{array}$ & $10 \mathrm{KW}, 100 \mathrm{VAR}$ & $0.55 \Omega$ & $28 \%$ & $3.1 \mathrm{KV}$ & $98.46 \%$ & $\begin{array}{c}1.54 \\
\%\end{array}$ \\
\hline III & $\begin{array}{c}50 \mathrm{KW}, 100 \\
\mathrm{VAR}\end{array}$ & $10 \mathrm{KW}, 100 \mathrm{VAR}$ & $0.55 \Omega$ & $80 \%$ & $8.5 \mathrm{KV}$ & $97.97 \%$ & $\begin{array}{c}2.03 \\
\%\end{array}$ \\
\hline IV & $\begin{array}{c}1 \mathrm{MW}, 100 \\
\mathrm{VAR}\end{array}$ & $10 \mathrm{KW}, 100 \mathrm{VAR}$ & $0.55 \Omega$ & $97.12 \%$ & $13 \mathrm{KV}$ & $99.39 \%$ & 0.61 \\
\hline
\end{tabular}

Hence, simulation results shows that by increasing the dc storage the effect of voltage sag in output voltage is decreased. As can be seen from table 2 with increment in load 1 while keeping load 2 constant the voltage sag continuously increases which can be compensated by proportional increase in the dc energy storage. 


\section{CONCLUSION}

Hence foregoing analysis shows the impact of DVR and dc energy storage on voltage sag compensation. Consideration on different active power of load with varying dc energy storage shows that with increasing values of load there is an enhancement of voltage sag which can be further compensated by adjusting the values of dc energy storage. The simulation results are compared on the basis of output voltages and output waveforms shows that DVR is fairly efficient for compensation of sag and swell.

Further dimensions to this work can be added by analyzing other disturbances of power quality like voltage swell, harmonics etc. Various sag compensations cases are discussed while varying the active power of load.

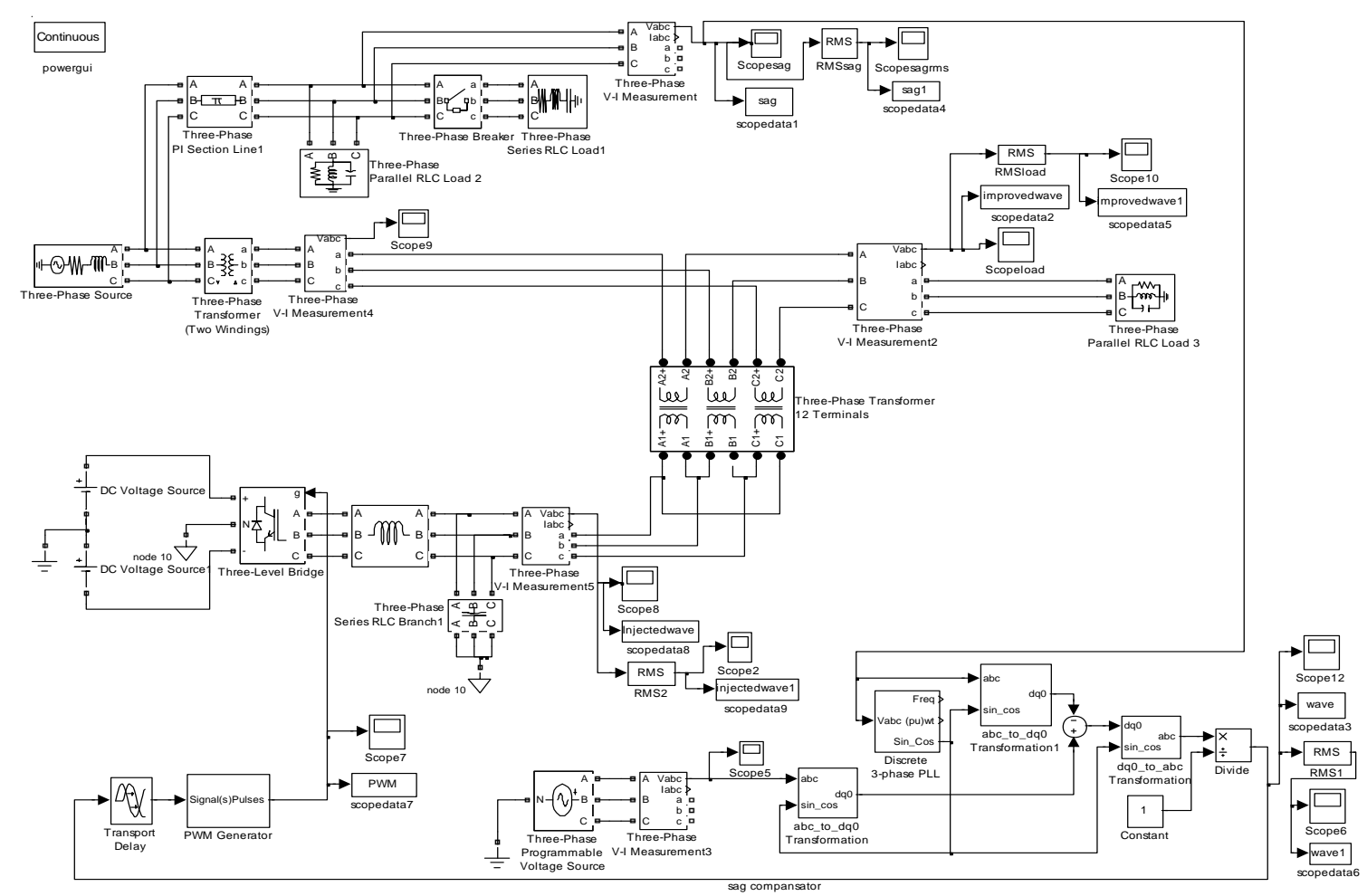

Fig.4. Simulation model of the DVR

\section{REFERENCES}

[1] Mladen Kezunovic, “A Novel Software Implementation Concept for Power Quality Study”, IEEE Transactions on power delivery, vol. 17, NO. 2, April 2002.

[2] Boris Bizjak, Peter Planinšič, “Classification of Power Disturbances using Fuzzy Logic”, University of Maribor - FERI, Smetanova 17, Maribor, SI - 2000.

[3] J. G. Nielsen, M. Newman, H. Nielsen, and F. Blaabjerg, "Control and Testing of DVR at Medium Voltage", IEEE Transaction on Power Electronics, Vol.19.No.3, May 2004.

[4] Burke J.J., Grifith D.C., and Ward J., "Power quality-Two different perspectives", IEEE Trans. on Power Delivery, vol. 5, pp. $1501-1513,1990$.

[5] Margo P., M. Heri P., M. Ashari, Hendrik M. and T. Hiyama, "Compensation of Balanced and Unbalanced Voltage Sags using Dynamic Voltage Restorer Based on Fuzzy Polar Control”, International Journal of Applied Engineering Research, ISSN 0973 4562 Volume 3, Number 3, pp. 879-890, 2008.

[6] Y. W. Lie, F. Blaabjerg, D. M. Vilathgamuwa, P. C. Loh, "Design and Comparison of High Performance Stationary-Frame Controllers for DVR Implementation”, IEEE Transactions on Power Electronics, Vol.22, No.2, March 2007. 
[7] P.W. Lehn and MR. Iravani, "Experimental Evaluation of STATCOM Closed Loop Dynamics", IEEE Trans. Power Delivery, vol. 13, no.4, pp.1378-1384 October 1998.

[8] Rosli Omar, Nasrudin Abd Rahim, Marizan Sulaiman, "Modeling and 8simulation for voltage sags/swells mitigation using dynamic voltage restorer (dvr)", Journal of Theoretical and Applied Information Technology, JATIT, 2005 - 2009.

[9] S. Chen, G. Joos, L. Lopes, and W. Guo, "A nonlinear control method of dynamic voltage restorers", IEEE 33rd Annual Power Electronics Specialists Conference, pp. 88- 93, 2002.

[10] H.P. Tiwari, Sunil Kumar Gupta, "Dynamic Voltage Restorer Based on Load Condition", International Journal of Innovation, Management and Technology, Vol. 1, No. 1, ISSN: 2010-0248, April 2010.

[11] Toni Wunderline and Peter Dhler, "Power Supply Quality Improvement with A Dynamic Voltage Restorer (DVR)", IEEE Transaction, 1998.

[12] Carl N.M.Ho, Henery and S.H. Chaung, "Fast Dynamic Control Scheme for Capacitor- Supported Dynamic Voltage Restorer: Design Issues, Implementation and Analysis", IEEE Transaction, 2007.

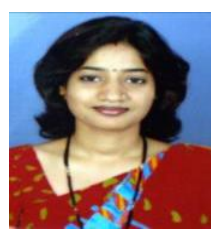

${ }^{1}$ Anita Pakharia obtained her B.E. (Electrical Engineering) in year 2005 and pursuing M. Tech. in Power systems (batch 2009) from Poornima College of Engineering, Jaipur. She is presently Assistant Professor in the Department of Electrical Engineering at the Global College of Technology, Jaipur. She has more than 6 years of teaching experience. She has published five papers in National/ International Conferences. Her field of interest includes Power Systems, Generation of electrical power, Power electronics, Drives and Non-conventional energy sources etc.

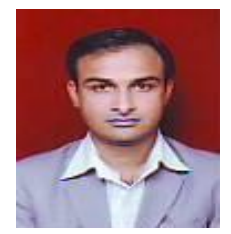

${ }^{2}$ Manoj Gupta received B.E. (Electrical) and M. Tech. degree from Malaviya National Institute of Technology (MNIT), Jaipur, India in 1996 and 2006 respectively. In 1997, he joined as Electrical Engineer in Pyrites, Phosphates and chemicals Ltd. (A Govt. of India Undertaking), Sikar, Rajasthan. In 2001, he joined as Lecturer in Department of Electrical Engineering, Poornima College of Engineering, Jaipur, India and now working as Associate Professor in Department of Electrical Engineering in the same. His field of interest includes power quality, signal/ image processing, electrical machines and drives. Mr. Gupta is a life member of Indian Society for Technical Education (ISTE), and Indian Society of Lighting Engineers (ISLE). 